\title{
The Department-based Job Duties Analysis
}

\author{
Yingzhen Zhou \\ Economics and management college of Three \\ Gorges University \\ Yichang, China \\ zhouyz@ctgu.edu.cn
}

\author{
Jiang Wei Li \\ Economics and management college of Three \\ Gorges University \\ Yichang, China \\ jw_jim@163.com
}

\begin{abstract}
In the present management theory and practice, the job duties analysis is mainly based on the position analysis. However, this kind of analytical method often exacerbates the problems in business management. Especially in China, with such a special economic and social environment, it is even harder to meet the needs of enterprise's development with the position-based job duties analysis. Department-based job duties analysis changes the idea of "one position, one table" into "one department, one table", which offers a set of new ideas on enterprise management and will greatly promote the development of business management activities.
\end{abstract}

Keywords-Job analysis; Responsibilities decomposition; Sector-based

\section{THE PERPLEXITY IN JOB DUTIES ANALYSIS}

As we all know, job analysis is the foundation of Human Resource Management (HRM), among which, the most difficult and important point is the decomposition of job duties. However, in management practice, we always encounter various problems, such as buck-passing among the employees, great losses caused by the employees' unwillingness to do the task and employees' endless complaints about the workload. All these problems are resulted by improper job analysis, or more accurately, the poor decomposition of the job duties and the job standards. When coming across those problems, managers will inquire the descriptions of positions. However, they always get confused and cannot handle them.

From the long-term human resources management research and practice we explored a new set of analytical method of job duties (job standards): the department-based job duties analysis. This method can easily solve the difficult problems in analysis process, for example, the poor decomposition of the job duties and working without standards, and achieve the management objective that "Everything is done, everybody has something to do and everything has its standard".

\section{THE FUNDAMENTAL PHILOSOPHY OF "THE DEPARTMENT-BASED JOB DUTIES ANALYSIS"}

The department-based job duties analysis breaks the existing management thought "one position, one table" in management practices, and carries out the idea of "one department, one table "which takes department as the smallest unit. According to "one department, one table", job duties are subdivided, which realizes the complete decomposition of the job duties (job standards).

The main contents are as follows. At first, according to the enterprise' business process, we decompose the main service objects of each department, that is the department customers (including both the internal and external customers) based on the departments and oriented by the enterprise strategy. Secondly, on the basis of a good knowledge of the customers, we decompose the needs of each customer (mainly referring to certain goods or service), switch the associated customer needs with the job duties of the department after the screening of Human Resource Department and then identify the overall needs of all the customers. In this way, we can decompose the job duties of the department completely. Finally, as for customers, they can evaluate the service and give their relevant requirements and standards in five aspects: time limit, quantity, quality, safety and cost. By doing this, the customers' requirements and standards are converted to the job standards of the department service. Thus, the complete decomposition of job duties can be easily achieved.

Through two rounds of screening, we convert the customers' (including internal and external customers) needs and relevant service standards to the job duties and standards to achieve the management objective that "Everything is done, everybody has something to do and everything has its standard".

\section{THE IMPLEMENTATION STEPS OF THE \\ “DEPARTMENT-BASED JOB DUTIES ANALYSIS.}

\section{A. Find Department Customers (Both Internal and External Customers)}

Since everything real is rational, every department has its value of existence, which is based on the service for the customers. Department customers can be any departments within the company as well as certain business units or related government departments. For example, customers of the Finance Department can be Human Resources Department, Marketing Department, relevant Financial Institutions or the Tax Authorities. The first step of the department-based job duties analysis is to look for the department customers according to the company's business process, oriented by the company strategy. Looking for the department customers lays the foundation for the complete 
decomposition of departmental duties (see the first column of Schedule 1).

\section{B. Determinate and Screen Customers' Needs and Quantitative Job Standards.}

Having found out all of the service objects (customers), we begin to decompose and screen the needs of customers and service standards that each department is required to offer to the customers, including goods and services.

In management practice, we mainly define job duties of a certain department according to service requirements required by customers. However, during the process of business consulting, we find that the customers tend to raise various and unreasonable requirements and they are particular about the service quality in order to maximize their own interest. These requirements not only increase workload of related departments, but also cause the waste of resources, frictions among departments as well as the failure of meeting the requirements.

In order to resolve these problems effectively, a special Committee of the Job Duty Evaluation and Screening is organized by the Human Resource Department, covering the staff in Customer Department and Service Department, the leaders and external experts, to screen the requirements required by the customers. Members of the Committee screen the relevant job duties (standards) in accordance with the enterprise's situation and strategy. Only after the job duties being screened should they are brought into the department's job duty system.

Examples will make this clear. When a company defines the job duties (standards) of the Finance Department towards the Human Resource Department, the Human Resource Department makes the requirements at first, then the requirements of providing the financial data related to the performance evaluation by the Finance Department is approved by the committee. Therefore, submitting the financial data timely and accurately becomes the job duty of the Finance Department. Correspondingly, timeliness and quality are the job standards (appraisal standards) of this duty. In this way, after repeated decompositions and screenings, the job duties and job standards of Finance Department come into being.

\section{The Distribution of Department Duties to Specific Individuals}

After all work has been allotted, department managers, with the assistance of staff in Human Resource Department, will distribute all those departmental duties to each person (see the fourth column of schedule 1). The department manager is responsible for all the working results of his own department.

The new approach (distributing departmental duties to individuals) is more superior to the traditional way of duty assigned by position in terms of flexibility and great adaptability. With the assistance of staff in Human Resource Department, department managers distribute departmental responsibilities to each person according to their personal abilities and career advantages. If an employee resigns, the department manager could redistribute his duties to the other staff or a new employee. In this way, the adverse effects caused by the turnover of employees would be minimized.

\section{THE SIGNIFICANCE OF DEPARTMENT-BASED JOB DUTIES ANALYSIS}

The department-based job duties analysis has broken the traditional way of "one post, one table" to the idea of "one department, one table". It is of great practical significance to decompose duties to the specific person in charge. The importance is embodied in the following three aspects:

\section{A. The Department-based Job Duties Analysis is Efficient, Convenient, Dynamic and Adaptable.}

Management tool should be practical. The authors did a consulting project about a company's performance appraisal in Hubei Province, which already had a set of booklets about position specifications written by a well-known professor. However, it had been left behind because it was too cumbersome and hard to understand. Then we decomposed the company's job duties again based on departments, implementing "one department, one table", which was widely welcomed for its efficiency and convenience.

The department-based job duties analysis emphasizes on subdividing the department duties to the specific person in charge. The Department Director can make a dynamic adjustment about the distribution of department duties according to the specific department staff, and reduce the adverse effect on the department work to the maximum extent caused by the "employee turnover" which fully reflects the dynamics and adaptability of this job duties analysis.

\section{B. No flaw in the Plan. Complete Decomposition of the Job Duties can be Achieved.}

Through two rounds of screening, the department-based job duties analysis converts the customers' needs to the department duties, which can realize the complete decomposition of the job duties effectively and avoid the omission and unclear division of job duties.

In the first step, each department looks for its customers in all rounds to avoid the omissions of job duties effectively. In the second step, the customers put forward their requirements, and then the committee will screen these requirements. It affects a permanent cure for the improper decomposition of the job duties.

\section{It Connects with the Performance Appraisal System and Prevents Job Analysis Results Being Shelved.}

In management practice, we often have such a problem that the enterprises pay high price to ask a specialist to do job analysis projects, but their results just cannot be applied into practice.

The department-based job duties analysis quantifies the job standards of each duty according to the customer's requirements. Then, appropriate standards scores would be set for every job standard. The direct and indirect people in charge will be assessed according to the relevant job 
standards. The assessment results will be linked to their compensation directly. Thus, the performance appraisal system can be connected with job duties directly.

The department-based job duties analysis adopts the thought of "one department, one table" to connect the job analysis results with the immediate interest of the person in charge, which motivates the staff to follow relevant job standards to accomplish their job duties, and job analysis results on the shelf can be prevented effectively.

\section{REFERENCES}

[1] Henry Mintzberg,"Effective organization", Renmin University of China Press, Beijing.2007pp 170-189.

[2] He yu ming," Human resources management and control under the Group's control system in Human Resources Development and Management", Renmin University of China Press, Beijing, 2011, pp. 35-40.

[3] David Calvin," Organizational design of multi-unit companies in Human Resources Development and Management", Renmin University of China Press, Beijing, 2009.pp 20-25

[4] Martinez J1.JarilloJC.The evolution of research on coordination mechanisms in multinational corporations [J].Journal of International Business Studies, 1980, 20(3):489-514

TABLE I. JOB DUTIES AND APPRAISAL STANDARDS FOR FINANCIAL DEPARTMENT OF XX COMPANY

\begin{tabular}{|c|c|c|c|}
\hline Clients & Job Duties & Appraisal Standards & $\begin{array}{c}\text { People in } \\
\text { Charge }\end{array}$ \\
\hline $\begin{array}{c}\text { Tax } \\
\text { Department }\end{array}$ & $\begin{array}{l}\text { 1. Pay taxes according to the } \\
\text { law and zero out the taxes for } \\
\text { clients. }\end{array}$ & $\begin{array}{l}\text { 1.1 Actively coordinate relations with the Tax Department. Shall not let the company take } \\
\text { taxation risks due to dereliction of duty. (If the company is publicly criticized or fined } \\
\text { because of dereliction of duty, the directly responsible individual will be given } 10 \text { minus } \\
\text { each time, indirectly responsible individual } 5 \text { minus.) }\end{array}$ & $\mathrm{XXX}$ \\
\hline $\begin{array}{l}\text { Financial } \\
\text { Institutions }\end{array}$ & $\begin{array}{l}\text { 2. Coordinate relations with } \\
\text { Financial Intuitions. }\end{array}$ & $\begin{array}{l}\text { 2.1 Actively coordinate relations with Financial Institutions. Shall not let the company be } \\
\text { criticized or sanctioned due to dereliction of duty. (If the company is criticized or } \\
\text { sanctioned by Financial Institutions because of dereliction of duty, except for the special } \\
\text { circumstance that is beyond the control of the directly responsible individual, the directly } \\
\text { responsible individual will be given } 10 \text { minus each time, indirectly responsible individual } \\
5 \text { minus.) }\end{array}$ & $\mathrm{XXX}$ \\
\hline Company & $\begin{array}{l}\text { 3. Manage accounting } \\
\text { documents, accounting book } \\
\text { and financial statements. }\end{array}$ & $\begin{array}{l}\text { 3.1 Every income, cost and expense of each month shall be recorded in accounting book. } \\
\text { (If it fails to do so, the directly responsible individual will be given } 10 \text { minus each time, } \\
\text { indirectly responsible individual } 5 \text { minus.) } \\
\text { 3.2 The monthly financial statement shall be finished before } 6^{\text {th }} \text { of each month. (It can be } \\
\text { postponed in case of holidays.) (If one day later, the directly responsible individual will } \\
\text { be given } 10 \text { minus, indirectly responsible individual } 5 \text { minus.) } \\
\text { 3.3 Accounting documents, accounting book and financial statements shall be completed } \\
\text { and free of errors. (If there is one omission or error, the directly responsible individual } \\
\text { will be given } 4 \text { minus, indirectly responsible individual } 2 \text { minus.) }\end{array}$ & $\mathrm{XXX}$ \\
\hline Company & $\begin{array}{l}\text { 4. Pay the employees' salaries } \\
\text { in time. }\end{array}$ & $\begin{array}{l}\text { Complete salary review and enter them in the employees' accounts before } 11^{\text {th }} \text { of each } \\
\text { month. (It can be postponed in case of holidays.) (If one day later, the directly responsible } \\
\text { individual will be given } 10 \text { minus, indirectly responsible individual } 5 \text { minus, except for } \\
\text { the special circumstance that is beyond the control of the directly responsible individual. } \\
\text { If errors occur in payment, the directly responsible individual will be given } 10 \text { minus each } \\
\text { time, indirectly responsible individual } 5 \text { minus.) }\end{array}$ & $\mathrm{XXX}$ \\
\hline
\end{tabular}

